\title{
Graphene oxide-silver nanocomposites induce oxidative stress and apoptosis in caprine fetal fibroblast cells
}

Yu-Guo Yuan ( $\nabla_{\text {yyg9776430@163.com ) }}$

Yangzhou University https://orcid.org/0000-0001-5817-4247

Myeong-Don Joo

Gyeongsang National University

Jia-Lin Wang

Yangzhou University

Ayman Mesalam

Zagazig University

Abu Musa Md Talimur Reza

Polish Academy of Sciences

Yi Wang

Yangzhou University

Chen Qian

Yangzhou University

II-Keun Kong

Gyeongsang National University

\section{Research article}

Keywords: Graphene oxide (GO), Silver nanoparticles (AgNPs), Caprine fetal fibroblast cell, Reactive oxygen species (ROS), Apoptosis

Posted Date: August 6th, 2020

DOl: https://doi.org/10.21203/rs.3.rs-25800/v2

License: (c) (i) This work is licensed under a Creative Commons Attribution 4.0 International License.

Read Full License 


\section{Abstract}

Background: Graphene oxide (GO) has drawn much attention as excellent platform to which silver nanoparticles (AgNPs) can be anchored for the production of biomedical nanocomposites. Yet, the potential toxicity of reduced graphene oxide- silver nanoparticles (GO-AgNPs) nanocomposites to animal and human is complex to evaluate and remains largely unknown.

Results: Our data indicated that GO-AgNPs caused cytotoxicity in dose-dependent manner. GO-AgNPs induced significant cytotoxicity by the loss of cell viability, over-production of reactive oxygen species (ROS), increased leakage of lactate dehydrogenase (LDH) and level of malondialdehyde (MDA), increased expression of pro-apoptotic genes and decreased expression of anti-apoptotic genes.

Conclusions: This study demonstrated that GO-AgNPs potentially induced oxidative stress, which resulted in toxicity and cell apoptosis in caprine fetal fibroblast cell due to an increased generation of ROS. For antibacterial applications of GO-AgNPs nanocomposite in animal, the toxical effect must be further evaluated.

\section{Background}

Nanotechnology is related to the controlled design, characterization, production and application of nanosized materials, which are defined as small particles ranging in size between 1 and $100 \mathrm{~nm}$. The increasing application of nanoparticles in microelectronics, cosmetics, ceramics, catalysts and food has made them widely present in our lives and attracts increasing investment from governments and industry around the world [1-4]. Currently, because of their unique physiochemical properties, a growing number of nanomaterials have been applied in the area of biomedicine, which emphasis on the diagnostic and therapeutic purposes, such as cancer diagnosis and therapy, nanocarriers for targeted delivery of drugs and genes, design of novel candidate nanoscale constructs for drug development [5-10]. Consequently, the bio-application and biosafety of the nanomaterials need to be further explored. Despite their wide applications in several areas, many evidences suggested that some nanomaterials accumulates in human and animal tissue, such as heart, kidney and other organs [11-13], which modifies the transcription of genes related to transport pathways, nuclear signaling, endocytosis, reproductive behavior and general defenses [14,15]. Thus, any potential nanotoxicity should be thoroughly and carefully evaluated for promoting its safe application as a clinical agent.

Nanotoxicity involves the understanding of adverse biological effects of nanoparticles using both in vitro and in vivo model systems such as cell, tissue, organ and organism [16]. Several studies have been dedicated to examine the effects of graphene and graphene-related nanomaterials in various cell culture systems, including HeLa, MCF-7, SKBR3, NIH3T3, epithelial lung carcinoma, primary mouse embryonic fibroblast, human breast cancer and ovarian cancer [17-20]. Graphene and graphene related nanomaterials have been proved to lead to inflammatory response in the liver and kidney [21,22], genotoxicity and DNA damage [23], and adverse functional effects in the lungs, heart, intestine, and 
spleen [24-26]. In addition to the dependence of toxicity on surface functionalization, graphene, GO and reduced GO differentially induced toxicity is especially dependent on their sizes and oxidation state as well as the exposure concentrations and sensitivity of the employed in vitro and in vivo models $[27,28]$. Therefore, the higher concentration of graphene family nanomaterials seems unsafe to human and environmental health for long-term exposure [27].

In recent decades, graphene and graphene related nanocomposite have attracted much attention both in the industry and scientific community due to their unique physiochemical and biological properties [11]. Silver nanoparticles (AgNPs) are one of the most frequently used nanoparticles in a variety of biomedical applications [29]. Recent advances in nanotechnology have widened the potential combination of AgNPs with graphene-based nanocomposite, which offers a novel graphene-silver hybrid nanomaterials with unique functions in biomedical nanotechnology, and nanomedicine [30]. For example, AgNPs attaching on the surface of GO sheets can prevent AgNPs from aggregating, allow a more controlled release of AgNPs $^{+}$ions and lead to the increase antibacterial and anticancer activity [31,32]. Thus, humans, animal and the environment may be constantly exposed to a wide range of commercial products containing residues of AgNPs. The potential mechanisms involved in cellular damages and inner response pathways induced by grapheme related nanomaterials needed to be deeply investigated. AgNPs have been broadly used as antibacterial agents and for biomedical application in the healthcare industry. Our previous study demonstrated that AgNPs $(1 \mu \mathrm{g} / \mathrm{mL})$ exhibited substantial activity against multidrug resistant (MDR) bacteria in dairy goats [33]. Since, AgNPs can be translocated to the blood stream and distributed throughout vital organs such as the liver, kidney, lung and brain. Therefore, for safe applications of GOAgNPs as antibacterial agents for treatment of mastitis in the bovine and caprine, investigation of its toxicity and their potential risks is needed. The present study was conducted to investigate the effect of GO-AgNPs nanocomposites on caprine fetal fibroblast cells in vitro and to determine the underlying molecular mechanisms of their cytotoxicity. To our knowledge, this is the first report in caprine fetal fibroblast cells to demonstrate cellular responses and functional aspects of GO-AgNPs.

\section{Results}

\section{Characterization of GO-AgNPs}

TEM analysis was conducted to confirm the structural and surface morphology of the GO-AgNPs composites. The size distribution of the GO-AgNPs was about $20 \mathrm{~nm}$ as shown in the image of TEM (Fig. 1). GO-AgNPs images clearly showed transparent, single-layer sheets containing flake-like wrinkles in which AgNPs were homogeneously arranged on the micron scale of the GO sheets, which presented no evidence of agglomeration.

\section{Effect of GO-AgNPs on caprine fetal fibroblast cells viability}


For assessment of the potential cytotoxic effect of GO-AgNPs on caprine fetal fibroblast cells, the cell viability following GO-AgNPs treatment was determined by CCK-8 assay. As shown in Fig. 2, there were no significant differences in cell viability between control cells and those exposed to $1 \mu \mathrm{g} / \mathrm{mL}$ GO-AgNPs for $24 \mathrm{~h}$, however, the viability of cells was significantly reduced when the concentration increased $(4,8,12$ and $16 \mu \mathrm{g} / \mathrm{mL}$ ), suggesting that GO-AgNPs induced toxicity in caprine fetal fibroblast cells in a dosedependent manner.

\section{Effect of GO-AgNPs on cell morphology}

The morphologies of caprine fetal fibroblast cells after exposure to GO-AgNPs for $24 \mathrm{~h}$ were shown in Fig. 3. Caprine fetal fibroblast cells that had been exposed to $4 \mu \mathrm{g} / \mathrm{mL}$ and $8 \mu \mathrm{g} / \mathrm{mL}$ GO-AgNPs exhibited marked morphological changes and showed cell membrane breakage, with obvious reduction in number of cells in the group of $8 \mu \mathrm{g} / \mathrm{mL}$ GO-AgNPs. Scale bar $=20 \mu \mathrm{m}$.

\section{Effect of GO-AgNPs on reactive oxygen species (ROS) production}

To study whether GO-AgNPs induced oxidative impact involving in the apoptosis, the intracellular ROS level in caprine fetal fibroblast cells was analyzed. As shown in Fig. 4, the level of intracellular ROS in caprine fetal fibroblast cells was significantly increased $(P<0.05)$ when the cells were treated with 4 and $8 \mu \mathrm{g} / \mathrm{mL}$ of GO-AgNPs for $24 \mathrm{~h}$ compared to the control group.

\section{Effects of GO-AgNPs on apoptosis}

We went further to test the effect of GO-AgNPs on cell apoptosis. An Annexin V/PI apoptosis kit was ued to quantify the percentage of caprine fetal fibroblast cells undergoing apoptosis and dying by flow cytometry. The results suggested that the GO-AgNPs induced significant apoptosis and dead in caprine fetal fibroblast cells (Fig. 5).

\section{Effects of GO-AgNPs on superoxide dismutase (SOD) production}

Effects of GO-AgNPs on the production of the antioxidant indicator SOD in caprine fetal fibroblast cells were determined with SOD assay kit. As shown in Fig. 6, SOD activity decreased significantly $(P<0.05)$ in caprine fetal fibroblast cells treated with $4 \mu \mathrm{g} / \mathrm{mL}$ GO-AgNPs for $24 \mathrm{~h}$ when compared to the control group. Furthermore, treatment of caprine fetal fibroblast cells with $8 \mu \mathrm{g} / \mathrm{mLGO}-$ AgNPs decreased significantly $(P<0.01)$ in SOD activity compared to non-treated caprine fetal fibroblast cells. 


\section{Effects of GO-AgNPs on malondialdehyde (MDA) production}

The production of MDA in caprine fetal fibroblast cells was determined with the MDA assay kit after treated with different concentrations of GO-AgNPs $(0,4$ and $8 \mu \mathrm{g} / \mathrm{mL})$ for $24 \mathrm{~h}$. The results showed that levels of the oxidative damage indicator MDA increased significantly $(P<0.05)$ in the 4 and $8 \mu \mathrm{g} / \mathrm{mL}$ treated groups, when compared to the control group (Fig. 7).

\section{Effects of GO-AgNPs on lactate dehydrogenase (LDH)}

Caprine fetal fibroblast cells were treated with different concentrations of GO-AgNPs $(0,4$ and $8 \mu \mathrm{g} / \mathrm{mL})$ for $24 \mathrm{~h}$, and the level of leakage of LDH was measured. The results indicated that GO-AgNPs significantly increased the leakage level of LDH in caprine fetal fibroblast cells compared to the control group (Fig. 8; $\mathrm{P}<0.05$ ).

\section{Effects of GO-AgNPs on caspase-3 activity}

To confirm whether caspase- 3 is involved in apoptosis of caprine fetal fibroblast cells induced by GOAgNPs ( 4 and $8 \mu \mathrm{g} / \mathrm{mL}$ ), caspase-3 activity was measured by the caspase- 3 kit. The activity of caspase 3 in the 4 and $8 \mu \mathrm{g} / \mathrm{mL}$ group was significantly $(P<0.05)$ higher after treatment than that in the control group (Fig. 9).

\section{Effects of GO-AgNPs on gene expression}

To elucidate the possible molecular mechanisms underlying the negative effect of GO-AgNPs, the mRNA levels of pro- and anti-apoptotic, cell death and survival related genes caspase-3, Cyt-C, BAX, Smac,p53 and $B C L 2$ were investigated in caprine fetal fibroblast cells treated with GO-AgNPs (4 and $8 \mu \mathrm{g} / \mathrm{mL}$ ) for $24 \mathrm{~h}$ and compared with control. The results showed that the level of caspase-3, Cyt-C, BAX, Smac and p53 were significantly $(P<0.05)$ upregulated in the GO-AgNPs treated groups, compared to the control group (Fig. 10). However, the level of anti-apoptosis gene BCL2 in the GO-AgNPs treated group was significantly $(P<0.05)$ downregulated, compared with the control group (Fig. 10).

\section{Discussion}

Nanotechnology has become an indispensable field tool to develop various kinds of nanoparticles with unique properties [34]. As an efficient support material, graphene sheets can disperse and stabilize silver nanoparticles preventing their agglomeration, which open up a way for the nanomaterial development. Therefore, the combination of graphene and AgNPs based nanocomposites has been widely produced to 
physiology of organisms, which may have the potential toxicity both on human and animal health or ecosystems [26]. Therefore, the adverse effects of GO-AgNPs composites have been considered as a major limitation for its broad applications. Numerous studies have proved the toxicological effects of GOAgNPs nanocomposite on animal and human normal cells $[12,35,36]$. In the present study, a GO-AgNPs nanocomposite was synthesized using quercetin and was confirmed its surface and structural morphology, and the uniform distribution of AgNPs on the GO sheets with TEM, and investigated its toxic effect on caprine fetal fibroblast cells.

Humans could be directly exposed to AgNPs of many consumer products via the route of inhalation, dermal contact and oral ingestion [26]. Therefore, toxical effect of these products is required to ensure that they are safe to use. As cell lines are considered as an experimental models for testing nanomaterial toxic, several studies have demonstrated that AgNPs induced toxicity via oxidative stress and apoptosis in mouse and rat cell lines [37,38]. Cell viability is an important index of cytotoxicity, which is defined as the potential of tested AgNPs to induce cell death. AgNPs with a smaller size have the ability to enter into cells more easily by uptake and are distributed throughout the cytosol [39], and contacted with cell organelles. While the smaller AgNPs $(6 \mathrm{~nm})$ was reported to be non-toxic to mouse fibroblast line and human keratinocyte cell line [40]. Similar results were reported that $5 \mu \mathrm{g} / \mathrm{mL}$ rGO-Ag nanocomposite did not induce cytotoxicity in human normal cells (CHANG cell) but could slightly induce toxic effect on HepG2 cells [38], which ascribe the differences in toxicity mechanisms to cell type [41]. The present data showed that $20 \mathrm{~nm}$ GO-AgNPs reduced cell growth, viability and induced morphological changes in a concentration-dependent manner. In our previous study, GO-AgNPs significantly decreased the human ovarian cancer cell viability with an $\mathrm{IC}_{50}$ of $5 \mu \mathrm{g} / \mathrm{mL}$ [42], which is lower than that in the present study, suggesting that caprine fetal fibroblast cells are less sensitive to GO-AgNPs than human cancer or mouse cells. AgNPs with different sizes and surface coatings or without coatings are likely to contribute to these different results. Lopes et al [43] reported that coating-AgNPs had a better dispersion than AgNPs and was more fully exposed to the cells. When compared to L02 cells, HepG2 cells are more sensitive to AgNPs at the exposure level of $20-160 \mu \mathrm{g} / \mathrm{mL}$ [44].

One of the main mechanisms of toxicity induced by nanomaterial is that it causes oxidative stress through the generation of ROS and causes damage to cellular components including DNA damage, abnormal activation of transcription factors, depletion of antioxidant molecules, binding and disabling of proteins, and damage to the cell membrane [26]. Oxidative stress inducing ROS is one of the proposed toxicological mechanisms of various nanomaterials such as Ag or Ag-graphene nanocomposites, can cause mitochondrial damage, and initiation of lipid peroxidation $[42,45,46]$. Cytotoxicity of AgNPs is associated with increased production of ROS, which play an important role in apoptosis induced by AgNPs [47]. Compared to pristine AgNPs, GO-AgNPs significantly induced generation of ROS in the macrophage in a dose-dependent manner [48]. In current study, the level of ROS increased significantly at a 1.4- and 1.8-fold in caprine fetal fibroblast cells after treatment with 4 and $8 \mu \mathrm{g} / \mathrm{mL}$ GO-AgNPs for $24 \mathrm{~h}$. Our results are consistent with previous reports on various cancer cell lines with graphene and graphenerelated materials $[30,42]$. The up-regulated ROS level in caprine fetal fibroblast cells alters the 
mitochondrial functions and plays a key role in apoptosis induction, which proved by the data of Annexin V/PI double labeling assay and increasing level of caspase-3. The present data suggests that the possible mechanisms of GO-AgNPs-induced toxicity in caprine fetal fibroblast cells include the stimulation of oxidative stress, which results in apoptosis and is responsible for the upregulation of proapoptotic and down regulation of anti-apoptotic genes in caprine fetal fibroblast cells [30].

The increased level of MDA and LDH is generally considered to imply the cell injury. One of the adverse effects of oxidative stress is the lipid peroxidation of cell membranes. Many type of cells treated with AgNPs and GO showed significantly increased levels of MDA, which is one of the final products of polyunsaturated fatty acids peroxidation in the cells [17,30,49-51]. Assessing the release of intracellular LDH in cell, which resulted from the breakdown and alteration in the permeability of the plasma membrane, is one of marker for estimating cytotoxicity [30,46]. rGO-Ag increases LDH leakage in human cancer cells, thus resulting in cell death $[30,42,52]$. The present data indicated that the mechanism of increased level of MDA and LDH in GO-AgNPs-treated caprine fetal fibroblast cells may be due to the strong hydrophobic interactions with the cell membrane and ROS formation, which influenced the viability and proliferation of cells, suggesting the possible cytotoxicity of GO-AgNPs on caprine fetal fibroblast cells.

The apoptosis in cell is a highly conserved mechanism, and ROS is an important factor involved in the apoptotic process [53]. ROS induced by nanomaterial could result in nuclear DNA damages and leakage of lipids, proteins and carbohydrates in the cell $[33,51]$. ROS production and lipid peroxidation induced by GO-AgNPs affected cellular redox homeostasis and decrease antioxidant levels [51]. It is well known that SOD plays an important role in antioxidant defense against oxidative stress in cells that can combat the accumulation of ROS and reduce the oxidative injury. A decrease of SOD activity is an indicator of impairment of the protective mechanisms and significantly contributes to cell damage [54]. It has been reported that, AgNPs directly interacted with SOD and CAT, altered the expression and activity of antioxidant enzymes (CAT, SOD and GPX) [54]. The present data showed that the level of SOD significantly decreased in GO-AgNPs-treated caprine fetal fibroblast cells. It may suggest that GO-AgNPs decrease levels of antioxidant molecules in the cells, which may be the reason for the cause of cytotoxicity.

Apoptotic and anti-apoptotic genes play an important role in cell survival and death. Several studies have reported that the mechanisms of GO- and graphene oxide silver nanocomposite-induced toxicity in numerous human cancer cell lines due to include oxidative stress, DNA damage, and apoptosis [12]. A similar study reported that GO-AgNPs can cause oxidative damage, leakage of LDH, and enhance expression of apoptotic genes of $p 53$, caspase-3, caspase-9, Bax, and c-myc, thus lead to mitochondrial dysfunction and trigger apoptosis [55]. All apoptotic pathways appear to terminate in the activation of the caspase family of proteases [56]. Moreover, oxidative stress induced by GO-AgNPs is reported to increase the total expression of Bax in a dose dependent manner and also down-regulate the expression of the anti-apoptotic gene of BCL-2 [52]. The present data showed that GO-AgNPs up-regulated the expression Loading [MathJax]/jax/output/CommonHTML/jax.js $3 a x$, Smac and c-myc, and down-regulated anti-apoptotic 
genes such as $B c /-2$. Similarly, rGO-Ag reported to cause dynamic balance troubles in the level of Bcl-xl and $\mathrm{Bcl}-2$, and downregulation of c-myc triggers apoptosis along with p53 [55], which may induced apoptosis in caprine fetal fibroblast cells.

\section{Conclusion}

Collectively, the synthesized GO-AgNPs nanocomposite displayed cytotoxicity to caprine fetal fibroblast cells at the concentration of 4 and $8 \mu \mathrm{g} / \mathrm{mL}$ with apoptotic induction by loss of proliferation and cell viability, enhancing production of ROS, decrease levels of anti-apoptotic genes and increase expression of pro-apoptotic genes. In addition to the dependence of toxicity on GO, AgNPs may play an important role in cellular toxicity, suggesting that the combination of GO and AgNPs served either as competence factors or acted synergistically to enhance the cytotoxicity towards caprine fetal fibroblast cells. These data provide toxicological information in assessing the toxical effects of GO-AgNPs in cell of large animals.

\section{Materials And Methods}

\section{Chemicals}

All chemicals and reagents were purchased from Sigma-Aldrich (St. Louis, MO, USA) unless otherwise stated.

\section{Synthesis and characterization of GO-AgNPs}

GO-AgNPs nanocomposites were synthesized using the biomolecule quercetin as described previously [42], then lyophilized and keep in lab at $4^{\circ} \mathrm{C}$ till usage. Briefly, $50 \mathrm{mg} \mathrm{GO}$ was dispersed in $30 \mathrm{~mL}$ water and sonicated for $60 \mathrm{~min}$. One $\mathrm{mM} \mathrm{AgNO}_{3}$ were dissolved in $15 \mathrm{~mL}$ water in a $500 \mathrm{~mL}$ round-bottom flask. $30 \mathrm{~mL}$ of the $\mathrm{GO}$ dispersion was added, followed by addition of $5 \mathrm{~mL}$ of aqueous $1 \mathrm{mM}$ quercetin, and then stirred at $60^{\circ} \mathrm{C}$ for $12 \mathrm{~h}$. The resultant mixture was washed and centrifuged three times with water. Physicochemical characterization of GO-AgNPs were checked by fourier-transform infrared and Xray diffraction. The size and shape were observed under a transmission electron microscope (TEM; HT7800, Hitachi High-Technologies Corporation, Tokyo, Japan).

\section{Cell culture}

Caprine fetal fibroblast cells were isolated from 70-day old fetuses that were recovered surgically from a Boer goat obtained from Yangzhou University farm as previously described [57]. Briefly, the pregnant goats were anaesthetized using intramuscular injected with serazine hydrochloride $(0.02 \mathrm{~mL} / \mathrm{kg}$ body weight) and fetuses were collected. After removal of the head and internal organs, the remaining tissues 
Fisher Scientifc, Waltham, MA, USA). Then cells were washed three times, centrifuged to recover the cells, and cultured in Dulbecco's Modifed Eagle's Medium/F12 (DMEM/F12; Thermo Fisher Scientifc, Waltham, MA, USA) supplemented with $10 \%$ fetal bovine serum (FBS; Hangzhou Sijiqing Hangzhou, China) at $37^{\circ} \mathrm{C}$ in a humidified atmosphere of $5 \% \mathrm{CO}_{2}$. The cells were used at passage 3-10.

\section{Cell viability assay}

The cell viability was assessed by using an in vitro cell-counting assay kit (CCK-8; Rockville, MD, USA) as described previously [45]. Caprine fetal fibroblast cells were seeded on 96-well or 6-well plate and cultured for $24 \mathrm{~h}$ to allow adherence and stabilization. GO-AgNPs were sonicated for $20 \mathrm{~min}$ before use. Then the GO-AgNPs suspension was dispersed in DMEM/F12 for different concentrations $(1,4,8,12$ and 16 $\mu \mathrm{g} / \mathrm{mL}$ ) for $24 \mathrm{~h}$ at $37^{\circ} \mathrm{C}$. After culture, $10 \mu \mathrm{L}$ CCK-8 was added into each well and were incubated for 30 min at $37^{\circ} \mathrm{C}$ in the dark. The absorbance at $450 \mathrm{~nm}$ was measured using a microplate reader (BioTek Synergy 2, USA). According to the toxic data of $\mathrm{LC}_{50}$, the 4 and $8 \mu \mathrm{g} / \mathrm{mL}$ were selected for further experiments. This study was designed and blinded throughout all stages of the methodological process.

\section{Cell morphology}

Caprine fetal fibroblast cells were seeded into a 24-well plate for $24 \mathrm{~h}$, and then treated with the different concentrations of GO-AgNPs $(0,4$ and $8 \mu \mathrm{g} / \mathrm{mL})$ for $24 \mathrm{~h}$. The cell morphology was observed using an Olympus BX-UCB microscope (Tokyo, Japan).

\section{Annexin V-FITC/PI staining assay}

Caprine fetal fibroblast cells were seeded in a $75 \mathrm{~mm}$ culture plate and treated with different concentrations of GO-AgNPs $(0,4$ and $8 \mu \mathrm{g} / \mathrm{mL})$ for $24 \mathrm{~h}$. Cell apoptosis of caprine fetal fibroblast cells was detected by Annexin V-FITC and Propidium iodide (PI) staining assay according to manufacturer's instructions (Bipec Biopharma Corporation, USA). The cells were harvested, centrifuged for 5 min, rinsed with phosphate buffered saline (PBS) twice and resuspended in $500 \mu \mathrm{L}$ binding buffer containing $5 \mu \mathrm{L} \mathrm{PI}$

and $5 \mu \mathrm{L}$ V-FITC, and then incubated for $15 \mathrm{~min}$ at the room temperature in dark. The cell suspension was determined by flow cytometry to analyze the apoptotic rate.

\section{Measurement of ROS production}

Dichlorodihydroffluorescein diacetate (DCFH-DA) was used to detect intracellular ROS induced by different concentrations $(0,4$ and $8 \mu \mathrm{g} / \mathrm{mL})$ of GO-AgNPs [45]. Caprine fetal fibroblast cells were incubated in $10 \mu \mathrm{M} \mathrm{DCFH-DA}$ for $30 \mathrm{~min}$ at $37^{\circ} \mathrm{C}$. The cells were rinsed with PBS twice, and then the intracellular accumulation of ROS was measured by flow cytometry (Beckman-Coulter, USA). 


\section{Measurement of total SOD enzyme activity}

The SOD activity in caprine fetal fibroblast cells was detected following the the SOD assay kit (Beijing Solarbio Science \& Technology, Beijin, China) [45]. Cells were treated with 0, 4 and $8 \mu \mathrm{g} / \mathrm{mL}$ of GO-AgNPs for $24 \mathrm{~h}$. Cells were washed with PBS twice, and lysed with lysis buffer on the ice. The lysates were then centrifuged for $15 \mathrm{~min}$. Then, the supernatant was analsysed with a U-vis spectrophotometer (Nanodrop, Thermo, USA) at $550 \mathrm{~nm}$.

\section{Measurement of MDA production}

MDA, a convenient index for detecting the extent of lipid peroxidation reactions, was performed using the MDA assay kit (Beijing Solarbio Science \& Technology, Beijin, China) according to the manufacturer's instructions [58]. Cells were plated into 6-well plates at a density of $1.0 \times 10^{5}$ cells per well and cultured for $24 \mathrm{~h}$ to allow adherence before exposure to different concentrations $(0,4$ and $8 \mu \mathrm{g} / \mathrm{mL})$ of GO-AgNPs for $24 \mathrm{~h}$. Then the cells were washed with PBS twice and MDA activities were quantitated by reading optical densities using Synergy 2 multi-mode microplate reader (BioTek, USA) at $532 \mathrm{~nm}$.

\section{Measurement of LDH production}

Caprine fetal fibroblast cells were seeded in a 24-well culture plate, and treated with 0,4 and $8 \mu \mathrm{g} / \mathrm{mL}$ of GO-AgNPs for $24 \mathrm{~h}$. LDH level of cells in culture medium were quantified with LDH-

cytotoxicity assay Kit (Beijing Solarbio Science \& Technology, Beijin, China) [58]. The LDH activities were quantitated by reading optical densities at $490 \mathrm{~nm}$ using Synergy 2 multi-mode microplate reader (BioTek, USA).

\section{Measurement of caspase-3 activity}

Measurement of caspase-3 activity was analyzed with a caspase-3 activity kit (Beijing Solarbio Science \& Technology, Beijin, China) according to manufacturer's instructions. Briefly, caprine fetal fibroblast cells were seeded in a 24-well culture plate, and treated with 0,4 and $8 \mu \mathrm{g} / \mathrm{mL}$ GO-AgNPs for $24 \mathrm{~h}$. Then the cells were washed twice in PBS, lysed using lysis buffer, centrifuged at $16,000 \times \mathrm{g}$ at $4^{\circ} \mathrm{C}$ for $10 \mathrm{~min}$, and the supernatant was incubated with $10 \mu \mathrm{L}$ of caspase-3 substrate for $7 \mathrm{~h}$ at $37^{\circ} \mathrm{C}$. Substrate cleavage was measured at $405 \mathrm{~nm}$ using Synergy 2 multi-mode microplate reader (BioTek, USA).

\section{Quantitative reverse transcription PCR (RT-qPCR) analysis}

Total RNA was extracted from caprine fetal fibroblast cells using a RNA Isolation Kit (Thermo Scientifific, Waltham, MA, USA) according to the manufacturer s instructions. RNA samples were stored at $-80^{\circ} \mathrm{C}$ until Loading [MathJax]/jax/output/CommonHTML/jax.js scribed into first-strand cDNA using an iScript cDNA Synthesis 
Kit (Bio-Rad Laboratories, Hercules, CA, USA) according to the manufacturer's instructions. Quantitative analysis of the cDNA samples was performed using a CFX96 instrument (Bio-Rad Laboratories) using SYBR Green (Vazyme). Primers were designed based on the mRNA sequences of selected genes available in GenBank (Table 1). The PCR cycle was as follows: initial denaturation at $95^{\circ} \mathrm{C}$ for $30 \mathrm{~s}$, followed by 41 cycles of denaturation at $95^{\circ} \mathrm{C}$ for $15 \mathrm{~s}$, annealing at $60^{\circ} \mathrm{C}$ for $15 \mathrm{~s}$, and extension at $72^{\circ} \mathrm{C}$ for $30 \mathrm{~s}$. RTqPCR was performed independently four times. The target genes were quantified by the delta-delta $\mathrm{Ct}$ method using CFX manager V1.1 software (Bio-Rad Laboratories). Normalization was performed using $\beta$ actin as the reference gene.

\section{Statistical analysis}

The assessors were blinded to any stages of the methodological process. All results were expressed as mean \pm S.D. and analyzed by Origin 8.0 and SPSS 18.0 (IBM Corp., Armonk, NY, USA). The statistical significance of the changes between tested groups and control group were analyzed by one-way ANOVA followed Dunnett's multiple comparison. The level of statistical significance was set at $P<0.05$. All experiments were performed at least three times.

\section{Abbreviations}

GO: Graphene oxide; AgNPs: Silver nanoparticles; ROS: Reactive oxygen species; LDH: Lactate dehydrogenase; MDA: Malondialdehyde; SOD: Superoxide dismutase DCFH-DA: Dichlorodihydroffluorescein diacetate; PBS: Phosphate buffered saline; PI: Propidium iodide

\section{Declarations}

\section{Acknowledgments}

The authors thank the Yu-Ming Li for FACS analysis.

\section{Authors' contributions}

YGY designed the study, analyzed the data, drafted the manuscript and did experiment for nanoparticles and toxicity of cells. MDJ rand JLW performed cell culture. AM and AMMTR performed statistical analysis of the data and aided in data analysis. YW and CQ developed and performed qPCR analysis. CQ and IKK aided in reviewing and editing manuscript. All authors read and approved the final manuscript.

\section{Funding}

This work was supported by the Priority Academic Program Development of Jiangsu Higher Education Institutions (PAPD), the IPET grant through the Agri-Bio Industry Technology Development funded by Ministry of Agriculture, Food and Rural Affairs (MAFRA-117029-3 and 315017-5), the Open Project 
Corporation (SSX2020000012) and Joint International Research Laboratory of Agriculture and AgriProduct Safety, the Ministry of Education of China, Yangzhou University (JRK2018-11). The funder had no influence on the manuscript and its conclusions.

\section{Availability of data and materials}

The datasets analyzed during the current study are available from the corresponding author on reasonable request.

\section{Ethics approval and consent to participate}

The study was approved by the Animal Ethics Committee of Yangzhou University. Goats were handled in accordance with the Animal Ethics Procedures and Guidelines of the People's Republic of China. All procedures collecting $70 \mathrm{~d}$ caprine fetus were approved by the Animal Ethics Committee of Yangzhou University (no.2018.1109).

\section{Consent for publication}

Not applicable.

\section{Competing interests}

The authors declare no conflict of interest.

\section{Author details}

${ }^{1}$ College of Veterinary Medicine/Joint International Research Laboratory of Agriculture and Agri-Product Safety, the Ministry of Education of China, Yangzhou University, Yangzhou, Jiangsu 225009, China.

2 Jiangsu Co-innovation Center for Prevention and Control of Important Animal Infectious Diseases and Zoonoses/Jiangsu Key Laboratory of Zoonosis/Jiangsu Key Laboratory of Animal genetic Breeding and Molecular Design, College of Animal Science and Technology, Yangzhou University, Yangzhou, Jiangsu 225009, China. ${ }^{3}$ Division of Applied Life Science (BK21 Plus), Gyeongsang National University, Jinju 52828, Gyeongnam Province, Republic of Korea. ${ }^{4}$ Department of Theriogenology, Faculty of Veterinary Medicine, Zagazig University, Zagazig 44519, Egypt. ${ }^{5}$ Institute of Biochemistry and Biophysics Polish Academy of Sciences, Warsaw, Poland

\section{References}

1. Hoseinnejad M, Jafari SM, Katouzian I. Inorganic and metal nanoparticles and their antimicrobial activity in food packaging applications. Crit Rev Microbiol. 2018;44:161-81.

2. Knowles BR, Wagner P, Maclaughlin S, Higgins MJ, Molino PJ. Silica nanoparticles functionalized with zwitterionic sulfobetaine siloxane for application as a versatile antifouling coating system. ACS 
3. Fytianos G, Rahdar A, Kyzas GZ. Nanomaterials in Cosmetics: Recent Updates. Nanomaterials (Basel). 2020;10:979.

4. Lu X, Miousse IR, Pirela SV, Melnyk S, Koturbash I, Demokritou P. Short-term exposure to engineered nanomaterials affects cellular epigenome. Nanotoxicology. 2016;10:140-50.

5. Hu K, Wang $H$, Tang G, Huang T, Tang $X$, Liang $X$, et al. In vivo cancer dual-targeting and dualmodality imaging with functionalized quantum dots. J Nucl Med. 2015;56:1278-84.

6. Zhao W, Zhao Y, Wang Q, Liu T, Sun J, Zhang R. Remote light-responsive nanocarriers for controlled drug delivery: advances and perspectives. Small. 2019:e1903060.

7. Gonda A, Zhao N, Shah JV, Calvelli HR, Kantamneni H, Francis NL, et al. Engineering tumor-targeting nanoparticles as vehicles for precision nanomedicine. Med One. 2019;4:e190021.

8. Alirezaie Alavijeh A, Barati M, Barati M, Abbasi Dehkordi $\mathrm{H}$. The potential of magnetic nanoparticles for diagnosis and treatment of cancer based on body magnetic field and organ-on-the-chip. Adv Pharm Bull. 2019;9:360-73.

9. Lungu, II, Grumezescu AM, Volceanov A, Andronescu E. Nanobiomaterials used in cancer therapy: an up-to-date overview. Molecules. 2019;24:3547.

10. Chauhan VP, Jain RK. Strategies for advancing cancer nanomedicine. Nat Mater. 2013;12:958-62.

11. Lu N, Wang L, Lv M, Tang Z, Fan C. Graphene-based nanomaterials in biosystems. Nano Res. 2019;12:247-64.

12. Courtois P, Rorat A, Lemiere S, Guyoneaud R, Attard E, Levard C, et al. Ecotoxicology of silver nanoparticles and their derivatives introduced in soil with or without sewage sludge: A review of effects on microorganisms, plants and animals. Environ Pollut. 2019;253:578-98.

13. Brami C, Glover AR, Butt KR, Lowe CN. Effects of silver nanoparticles on survival, biomass change and avoidance behaviour of the endogeic earthworm Allolobophora chlorotica. Ecotoxicol Environ Saf. 2017;141:64-9.

14. Ong C, Lee QY, Cai Y, Liu X, Ding J, Yung LY, et al. Silver nanoparticles disrupt germline stem cell maintenance in the Drosophila testis. Sci Rep. 2016;6:20632.

15. Vadalasetty KP, Lauridsen C, Engberg RM, Vadalasetty R, Kutwin M, Chwalibog A, et al. Influence of silver nanoparticles on growth and health of broiler chickens after infection with campylobacter jejuni. BMC Vet Res. 2018;14:1.

16. Khanna P, Ong C, Bay BH, Baeg GH. Nanotoxicity: An interplay of oxidative stress, inflammation and cell death. Nanomaterials (Basel, Switzerland). 2015;5:1163-80.

17. Gurunathan S, Kim JH. Graphene oxide-silver nanoparticles nanocomposite stimulates differentiation in human neuroblastoma cancer cells (SH-SY5Y). Int J Mol Sci. 2017;18:2549.

18. Gies V, Zou S. Systematic toxicity investigation of graphene oxide: evaluation of assay selection, cell type, exposure period and flake size. Toxicol Res (Camb). 2018;7:93-101.

19. Gurunathan S, Han JW, Eppakayala V, Dayem AA, Kwon DN, Kim JH. Biocompatibility effects of hinlnairally cynthesized aranhene in nrimary mouse embryonic fibroblast cells. Nanoscale Res Lett. 
2013;8:393.

20. Thapa RK, Kim JH, Jeong JH, Shin BS, Choi HG, Yong CS, et al. Silver nanoparticle-embedded graphene oxide-methotrexate for targeted cancer treatment. Colloids Surf B Biointerfaces. 2017;153:95-103.

21. Syama S, Paul W, Sabareeswaran A, Mohanan PV. Raman spectroscopy for the detection of organ distribution and clearance of PEGylated reduced graphene oxide and biological consequences. Biomaterials. 2017;131:121-30.

22. Nurunnabi M, Khatun Z, Huh KM, Park SY, Lee D Y, Cho KJ, et al. In vivo biodistribution and toxicology of carboxylated graphene quantum dots. ACS Nano. 2013; 7:6858-67.

23. Ivask A, Voelcker NH, Seabrook SA, Hor M, Kirby JK, Fenech M, et al. DNA melting and genotoxicity induced by silver nanoparticles and graphene. Chem Res Toxicol. 2015;28:1023-35.

24. Hyun JS, Lee BS, Ryu HY, Sung JH, Chung KH, Yu IJ. Effects of repeated silver nanoparticles exposure on the histological structure and mucins of nasal respiratory mucosa in rats. Toxicol Lett. 2008;182:24-8.

25. Rosas-Hernandez H, Jimenez-Badillo S, Martinez-Cuevas PP, Gracia-Espino E, Terrones H, Terrones M, et al. Effects of 45-nm silver nanoparticles on coronary endothelial cells and isolated rat aortic rings. Toxicol Lett. 2009;191:305-13.

26. Rezvani E, Rafferty A, McGuinness C, Kennedy J. Adverse effects of nanosilver on human health and the environment. Acta Biomater. 2019;94:145-59.

27. Jia PP, Sun T, Junaid M, Yang L, Ma YB, Cui ZS, et al. Nanotoxicity of different sizes of graphene (G) and graphene oxide (GO) in vitro and in vivo. Environ Pollut. 2019;247:595-606.

28. Seabra AB, Paula AJ, de Lima R, Alves OL, Durán N. Nanotoxicity of graphene and graphene oxide. Chem Res Toxicol. 2014;27:159-68.

29. Ahmad S, Munir S, Zeb N, Ullah A, Khan B, Ali J, et al. Green nanotechnology: a review on green synthesis of silver nanoparticles-an ecofriendly approach. Int J Nanomedicine. 2019;14:5087-107.

30. Gurunathan S, Han JW, Park JH, Kim E, Choi YJ, Kwon DN, et al. Reduced graphene oxide-silver nanoparticle nanocomposite: a potential anticancer nanotherapy. Int J Nanomedicine. 2015;10:625776.

31. Gurunathan S, Hyun Park J, Choi YJ, Woong Han J, Kim JH. Synthesis of graphene oxide-silver nanoparticle nanocomposites: an efficient novel antibacterial agent. Current Nanoscience. 2016;12:762-73.

32. Cobos M, De-La-Pinta I, Quindós G, Fernández MJ, Fernández MD. Graphene Oxide-Silver Nanoparticle Nanohybrids: Synthesis, Characterization, and Antimicrobial Properties. Nanomaterials (Basel). 2020;10:376.

33. Yuan YG, Peng QL, Gurunathan S. Effects of Silver Nanoparticles on Multiple Drug-Resistant Strains of Staphylococcus aureus and Pseudomonas aeruginosa from Mastitis-Infected Goats: An Alternative Approach for Antimicrobial Therapy. Int J Mol Sci. 2017;18:569. 
34. Gurunathan S, Kim JH. Synthesis, toxicity, biocompatibility, and biomedical applications of graphene and graphene-related materials. Int J Nanomedicine. 2016;11:1927-45.

35. He K, Zeng Z, Chen A, Zeng G, Xiao R, Xu P, et al. Advancement of ag-graphene based nanocomposites: an overview of synthesis and its applications. Small. 2018;14:e1800871.

36. Ali D, Alarifi S, Alkahtani S, Almeer RS. Silver-doped graphene oxide nanocomposite triggers cytotoxicity and apoptosis in human hepatic normal and carcinoma cells. Int $\mathrm{J}$ Nanomedicine. 2018;13:5685-99.

37. Zhang XF, Choi YJ, Han JW, Park JH, Gurunathan S, Kim JH. Differential nanoreprotoxicity of silver nanoparticles in male somatic cells and spermatogonial stem cells. Int $\mathrm{J}$ Nanomedicine. 2015;10:1335-57.

38. Xu F, Piett C, Farkas S, Qazzaz M, Syed NI. Silver nanoparticles (AgNPs) cause degeneration of cytoskeleton and disrupt synaptic machinery of cultured cortical neurons. Mol Brain. 2013;6:29.

39. Hondroulis E, Liu C, Li CZ. Whole cell based electrical impedance sensing approach for a rapid nanotoxicity assay. Nanotechnology. 2010;21:315103.

40. Abdel-Mohsen AM, Abdel-Rahman RM, Fouda MM, Vojtova L, Uhrova L, Hassan AF, et al. Preparation, characterization and cytotoxicity of schizophyllan/silver nanoparticle composite. Carbohydr Polym. 2014;102:238-45.

41. Sahu SC, Zheng JW, Graham L, Chen L, Ihrie J, Yourick JJ, Sprando RL. Comparative cytotoxicity of nanosilver in human liver HepG2 and colon Caco2 cells in culture. J. Appl. Toxicol. 2014;34:1155-66.

42. Yuan YG, Wang YH, Xing HH, Gurunathan S. Quercetin-mediated synthesis of graphene oxide-silver nanoparticle nanocomposites: a suitable alternative nanotherapy for neuroblastoma. Int $J$ Nanomedicine. 2017;12:5819-39.

43. Lopes IMD, de Oliveira IM, Bargi-Souza P, Cavallin MD, Kolc CSM, Khalil NM, et al. Effects of silver nanoparticle exposure to the testicular antioxidant system during the prepubertal rat stage. Chem Res Toxicol. 2019;32:986-94.

44. Xue Y, Wang J, Huang Y, Gao X, Zhang T, Tang M, et al. Comparative cytotoxicity and apoptotic pathways induced by nanosilver in human liver HepG2 and L02 cells. Hum Exp Toxicol. 2018;37:1293-309.

45. Yuan YG, Zhang S, Hwang JY, Kong IK. Silver nanoparticles potentiates cytotoxicity and apoptotic potential of camptothecin in human cervical cancer cells. Oxid Med Cell Longev. 2018;2018:6121328.

46. Yuan YG, Peng QL, Gurunathan S. Silver nanoparticles enhance the apoptotic potential of gemcitabine in human ovarian cancer cells: combination therapy for effective cancer treatment. Int $J$ Nanomedicine. 2017;12:6487-502.

47. Lee YH, Cheng FY, Chiu HW, Tsai JC, Fang CY, Chen CW, et al. Cytotoxicity, oxidative stress, apoptosis and the autophagic effects of silver nanoparticles in mouse embryonic fibroblasts. Biomaterials. 2014; 35:4706-15. 
48. de Luna LA, de Moraes AC, Consonni SR, Pereira CD, Cadore S, Giorgio S, et al. Comparative in vitro toxicity of a graphene oxide-silver nanocomposite and the pristine counterparts toward macrophages. J Nanobiotechnology. 2016;14:12.

49. El-Sonbaty SM. Fungus-mediated synthesis of silver nanoparticles and evaluation of antitumor activity. Cancer Nanotechnol. 2013;4:73-9.

50. Liao KH, Lin YS, Macosko CW, Haynes CL. Cytotoxicity of graphene oxide and graphene in human erythrocytes and skin fibroblasts. ACS Appl Mater Interfaces. 2011;3:2607-15.

51. Yuan YG, Gurunathan S. Combination of graphene oxide-silver nanoparticle nanocomposites and cisplatin enhances apoptosis and autophagy in human cervical cancer cells. Int J Nanomedicine. 2017;12:6537-58.

52. Zhang XF, Huang FH, Zhang GL, Bai DP, Massimo DF, Huang YF, et al. Novel biomolecule lycopenereduced graphene oxide-silver nanoparticle enhances apoptotic potential of trichostatin $A$ in human ovarian cancer cells (SKOV3). Int J Nanomedicine. 2017;12:7551-75.

53. Yuan YG, Xu L, Zhang S, Mesalam A, Lee KL, Liu H, et al. Polydatin and I-CBP112 protects early bovine embryo against nicotinamide-induced mitochondrial dysfunction. Theriogenology. 2019;134:1-10.

54. Fang W, Chi Z, Li W, Zhang X, Zhang Q. Comparative study on the toxic mechanisms of medical nanosilver and silver ions on the antioxidant system of erythrocytes: from the aspects of antioxidant enzyme activities and molecular interaction mechanisms. J Nanobiotechnology. 2019;17:66.

55. Choi YJ, Gurunathan S, Kim JH. Graphene oxide-silver nanocomposite enhances cytotoxic and apoptotic potential of salinomycin in human ovarian cancer stem cells (OvCSCs): a novel approach for cancer therapy. Int J Mol Sci. 2018;19:710.

56. Mesalam A, Khan I, Lee KL, Song SH, Chowdhury MMR, Uddin Z, et al. 2-methoxystypandrone improves in vitro-produced bovine embryo quality through inhibition of IKBKB. Theriogenology. 2017;99:10-20.

57. Yuan YG, Song SZ, Zhu MM, He ZY, Lu R, Zhang T, et al. Human lactoferrin efficiently targeted into caprine beta-lactoglobulin locus with transcription activator-like effector nucleases. Asian-Australas J Anim Sci. 2017;30:1175-82.

58. Yuan YG, Peng QL, Gurunathan S. Combination of palladium nanoparticles and tubastatin-A potentiates apoptosis in human breast cancer cells: a novel therapeutic approach for cancer. Int J Nanomedicine. 2017;12:6503-20.

\section{Tables}

Table 1 Primers used for quantitative reverse transcription PCR analysis 


\begin{tabular}{|c|c|c|c|}
\hline Gene & Primer sequence (5- - 3) & Accession no. & Product size (bp) \\
\hline \multirow[t]{2}{*}{ caspase } & 3F: CCATGGTGAAGAAGGAATCATTT & AF068837.1 & 78 \\
\hline & R: TCCССТCTGAAGAAACTTGCTAA & & \\
\hline \multirow[t]{2}{*}{ Cyt-C } & F: CAGTGCCATACTGTGGAAAAGG & DQ176429.1 & 81 \\
\hline & R: TGACCTGTCTTTCGTCCAAACA & & \\
\hline \multirow[t]{2}{*}{$B A X$} & F: GCATCCACCAAGAAGCTGAG & XM_004015363.3 & 120 \\
\hline & R: CCGCCACTCGGAAAAAGAC & & \\
\hline \multirow[t]{2}{*}{ Smac } & F: TGTTCCAGTCGTGGCTAACTT & NM_001045882.1 & 1171 \\
\hline & R: AAAGACACAGCCСТCСТCATT & & \\
\hline \multirow[t]{2}{*}{$B C L 2$} & F: ATGTGTGTGGAGAGCGTCA & DQ152929.1 & 113 \\
\hline & R: AGAGACAGCCAGGAGAAATC & & \\
\hline \multirow[t]{2}{*}{$\beta$-actin } & F: TCACGGAGCGTGGCTACAG & U39357.1.1 & 63 \\
\hline & R: CCTTGATGTCACGGACGATTT & & \\
\hline
\end{tabular}

Abbreviations: $F$, forward; $R$, reverse

\section{Figures}




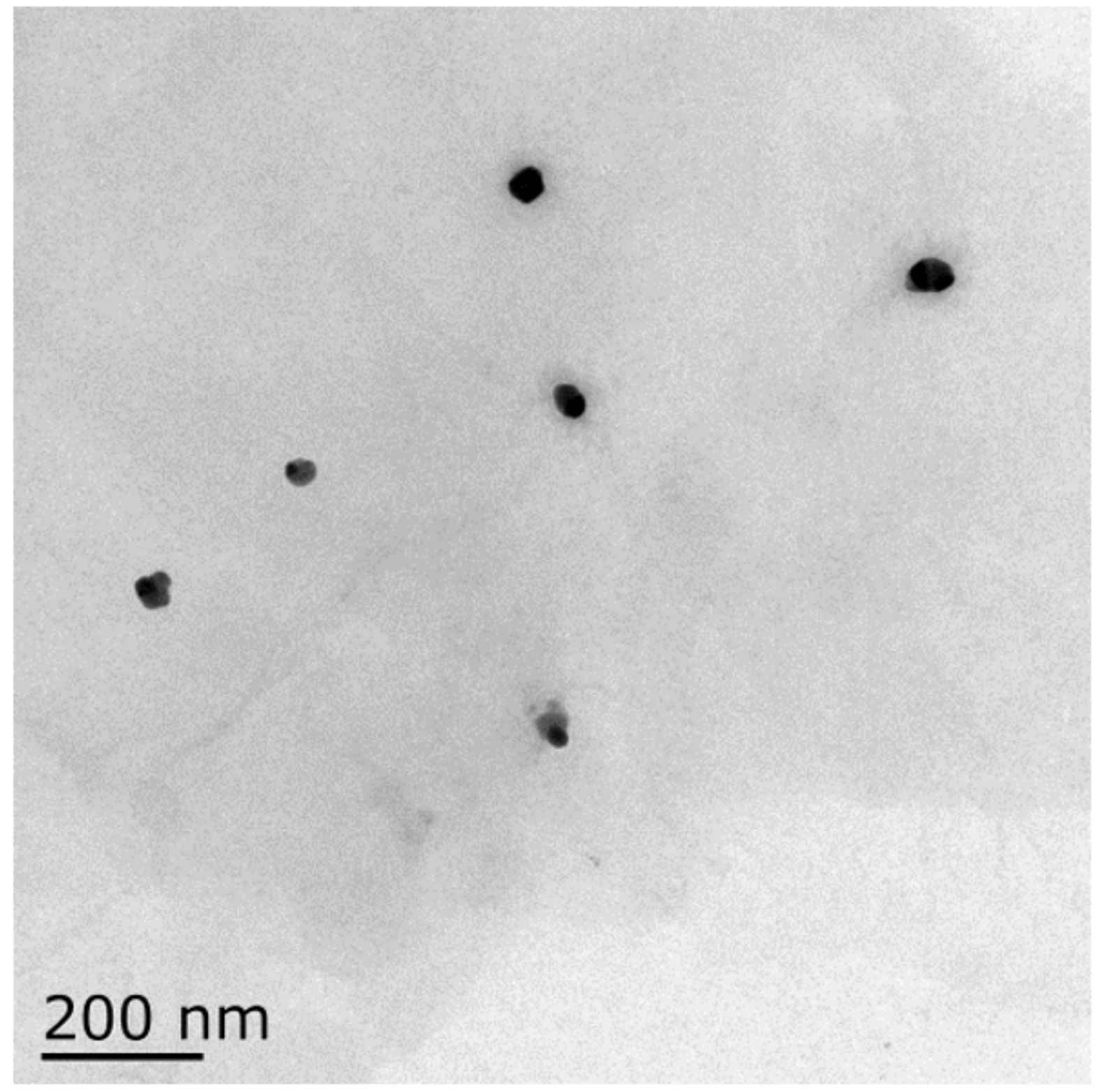

\section{Figure 1}

Size determination analysis of GO-AgNPs by Transmission electron microscope (TEM). TEM image showed that the size of GO-AgNPs was distributed about $20 \mathrm{~nm}$. 


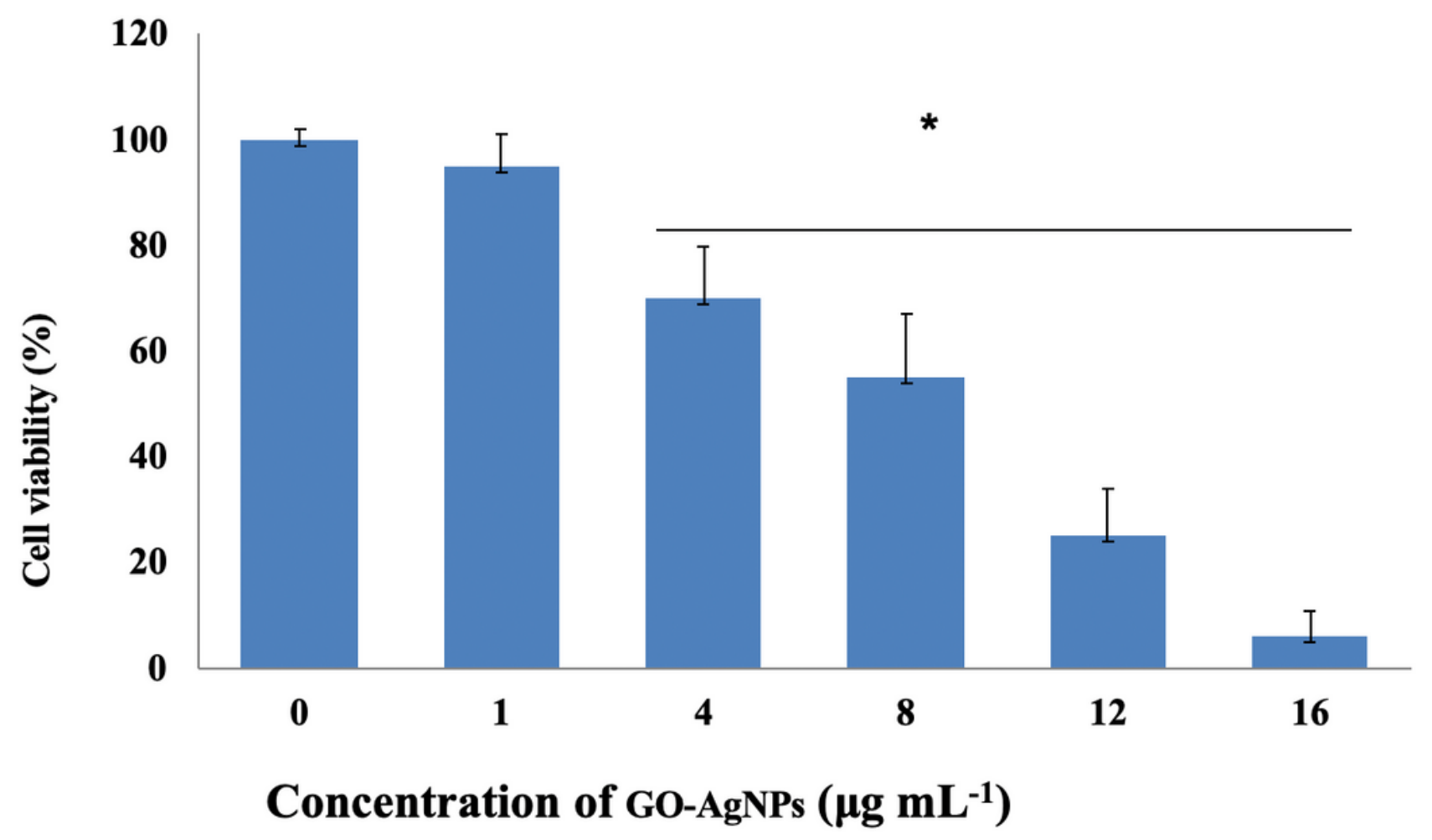

Figure 2

Effects of GO-AgNPs on the proliferation of caparine fetal fibroblast cells. Caparine fetal fibroblast cells were exposed to $0,1,4,8,12$ and $16 \mu \mathrm{g} / \mathrm{mL}$ of GO-AgNPs for $24 \mathrm{~h}$. The percentage of cell viability was then calculated relative to the control group $(0 \mu \mathrm{g} / \mathrm{mL})$. Values are presented as mean $\pm S D$ of four independent experiments. $\left({ }^{*} \mathrm{P}<0.05\right)$.

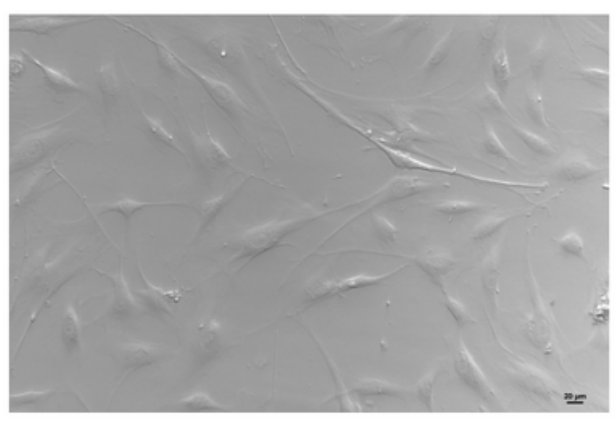

Control

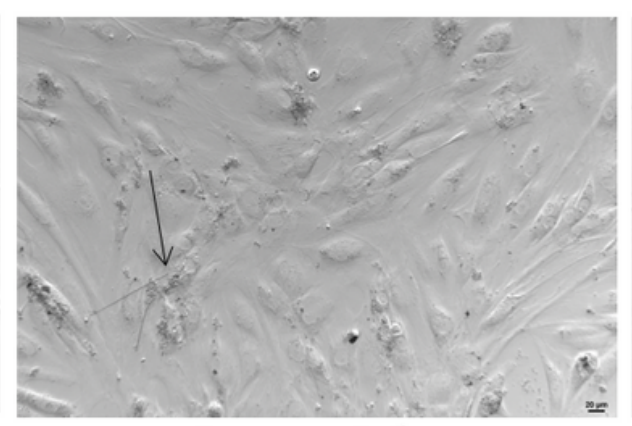

$4 \mu \mathrm{mL}^{-1}$

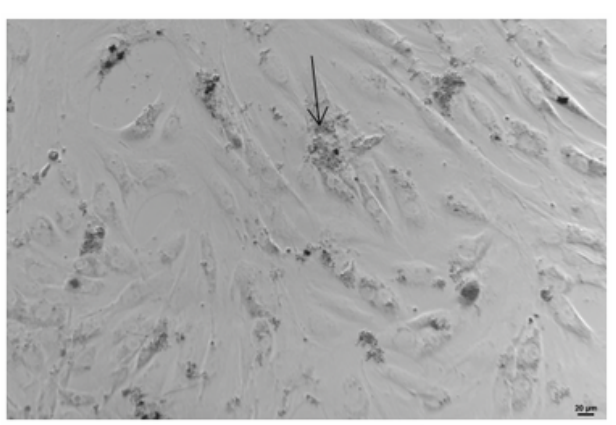

$8 \mu \mathrm{g} \mathrm{mL}^{-1}$

\section{Figure 3}

Cell morphology following treatment of GO-AgNPs. Caprine fetal fibroblast cells were treated with 0,4 and $8 \mu \mathrm{q} / \mathrm{mL}$ of GO-AaNPs for $24 \mathrm{~h}$ and then visualized under a phase-contrast microscope Loading [MathJax]/jax/output/CommonHTML/jax.js 
(magnification, 100x).

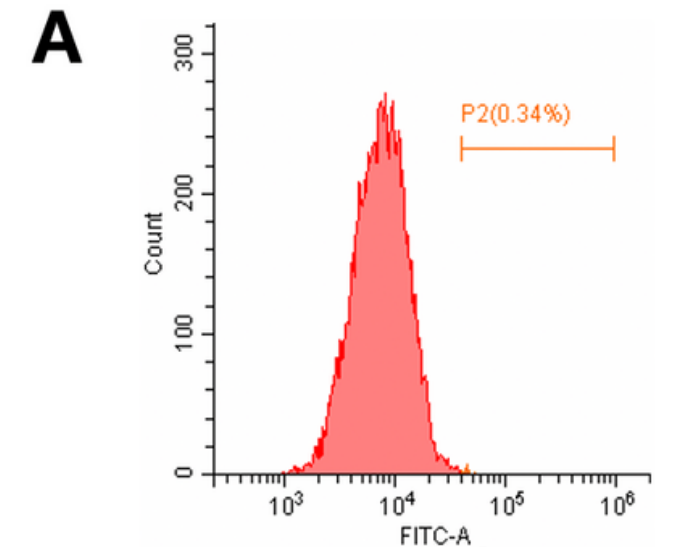

Control

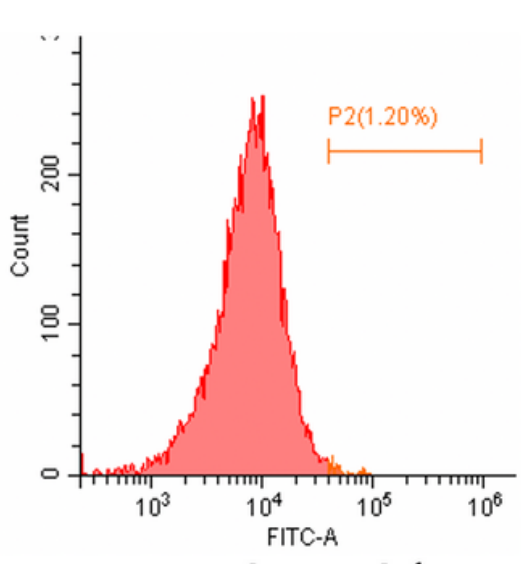

$4 \mu \mathrm{g} \mathrm{mL}-1$

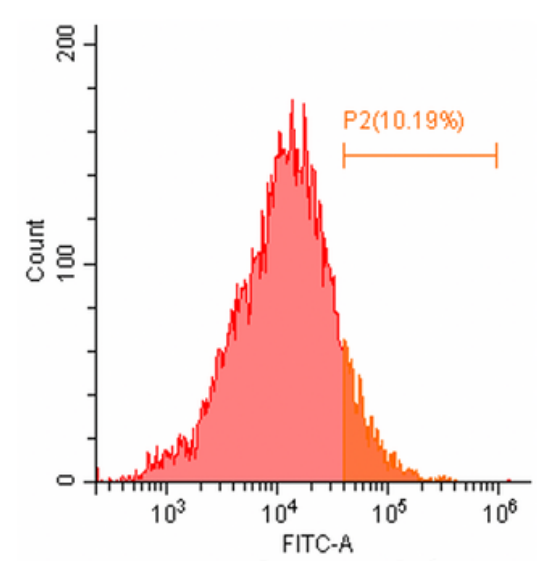

$8 \mu \mathrm{g} \mathrm{mL}^{-1}$

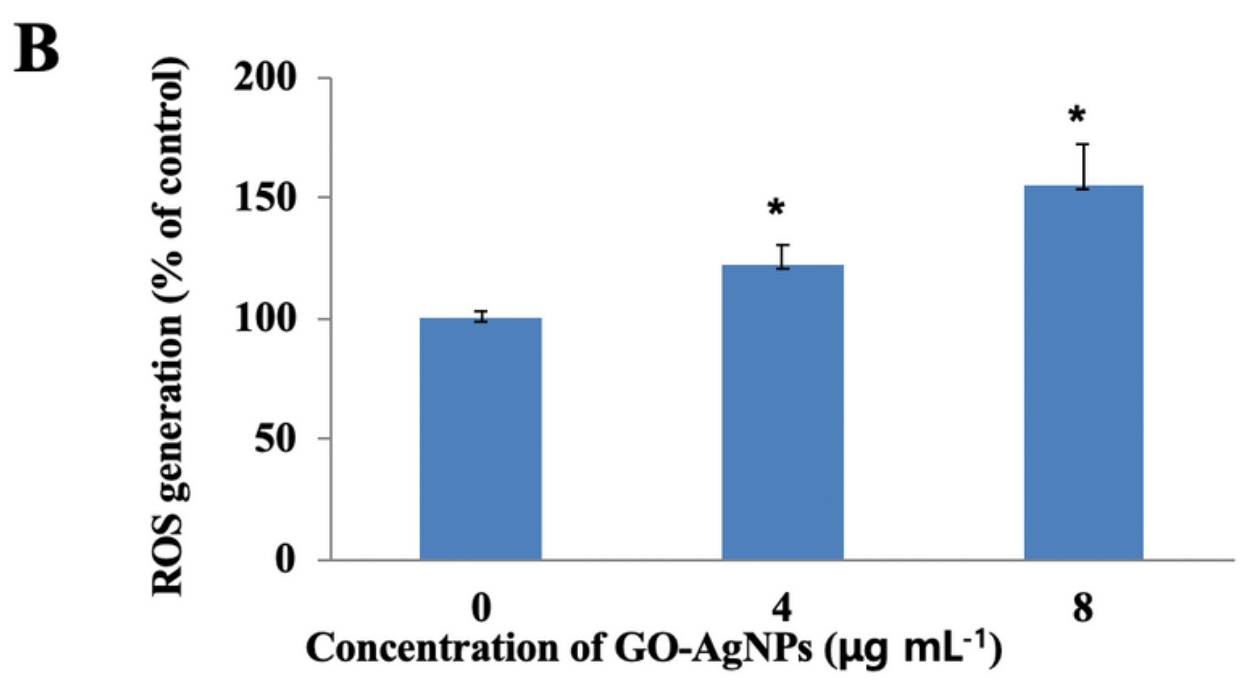

Figure 4

Total ROS generation in GO-AgNPs-treated cells. Caprine fetal fibroblast cells were treated with 0, 4 and 8 $\mu \mathrm{g} / \mathrm{mL}$ of GO-AgNPs for $24 \mathrm{~h}$ and analyzed by FACS (A). The percentage of ROS generation relative to the untreated control group $(0 \mu \mathrm{g} / \mathrm{mL})(B)$. Values are presented as mean $\pm S D$ of four independent experiments. ( $\left.{ }^{*}<<0.05\right)$. 
A

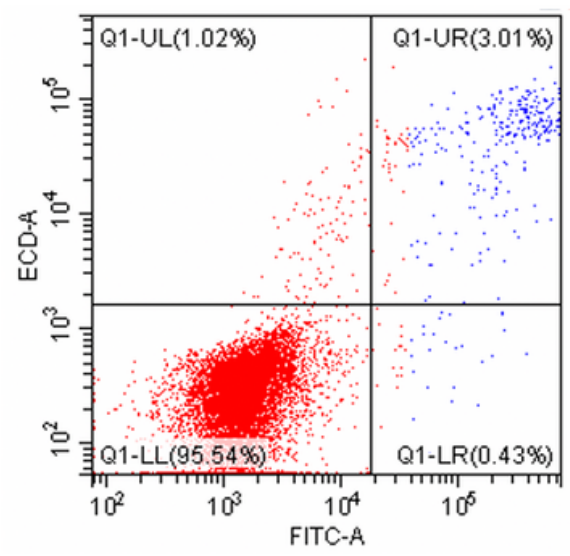

B

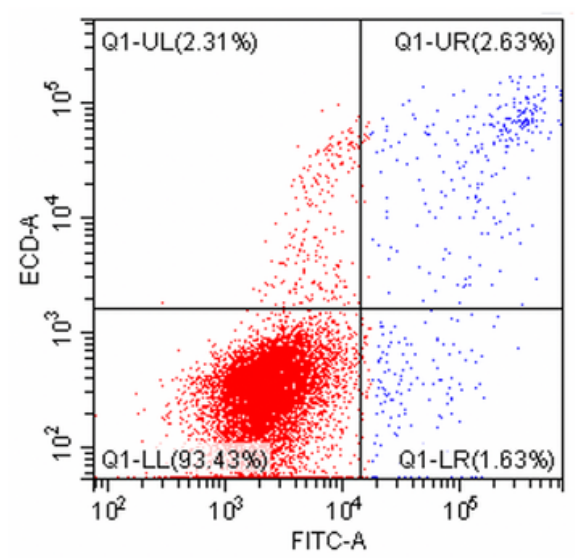

C

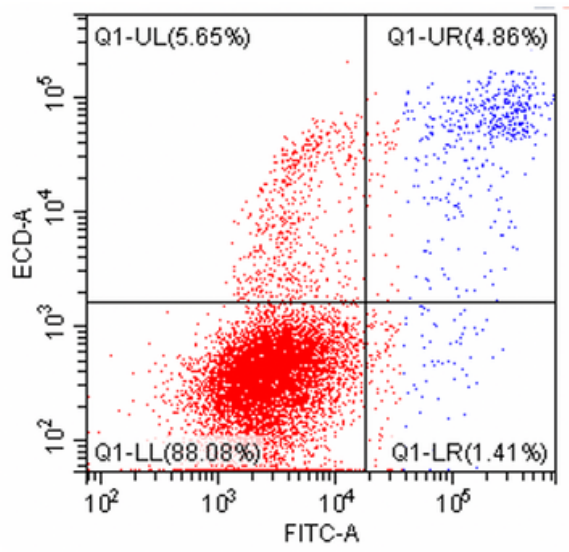

D

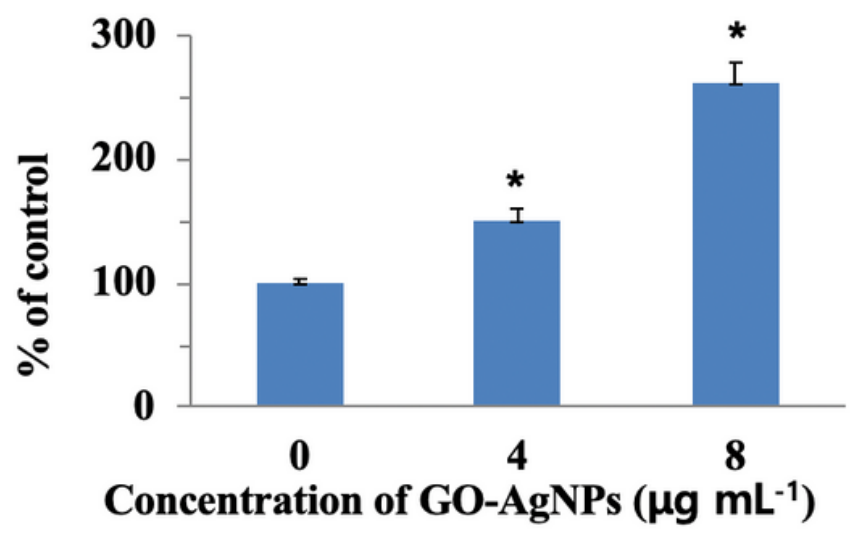

Figure 5

Evaluation of GO-AgNPs-induced apoptotic cell death with Annexin V-FITC/PI staining assay. Caprine fetal fibroblast cells were treated with 0 (A), 4 (B) and $8 \mu \mathrm{g} / \mathrm{mL}$ (C) of GO-AgNPs for $24 \mathrm{~h}$ and FACS was carried out for detection of fractions of early apoptotic, late apoptotic, and necrotic cell death of caprine fetal fibroblast cells. The corresponding linear diagram of flow cytometry was shown in (D). Values are presented as mean $\pm S D$ of five independent experiments. ( $\left.{ }^{\star} P<0.05\right)$. 


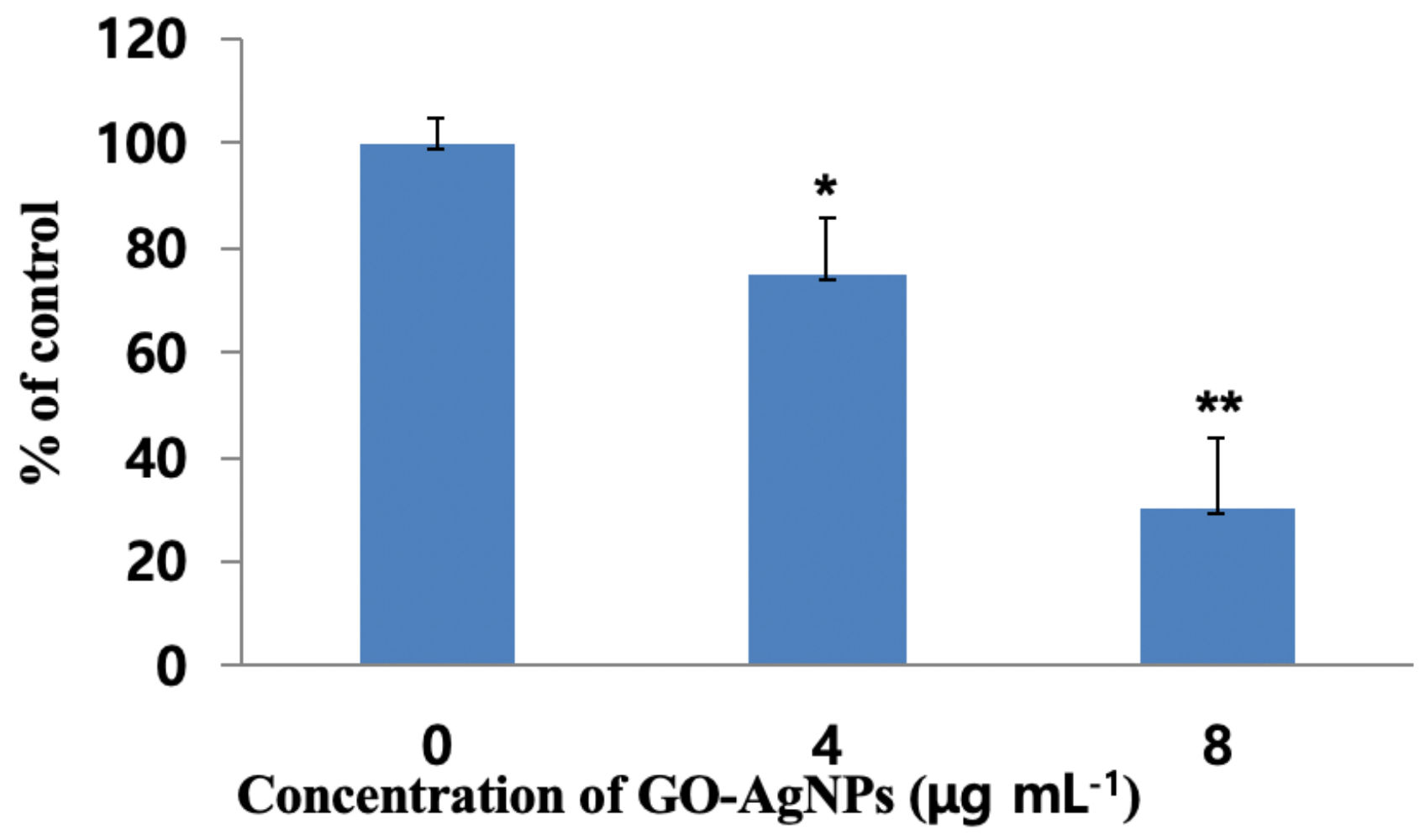

Figure 6

Measurement of SOD production in GO-AgNPs-treated cells. Caprine fetal fibroblast cells were treated with 0,4 and $8 \mu \mathrm{g} / \mathrm{mL}$ of GO-AgNPs for $24 \mathrm{~h}$. The percentage of SOD relative to the control group (0 $\mu \mathrm{g} / \mathrm{mL})$ was determined. Values are presented as mean $\pm S D$ of four independent experiments. $\left({ }^{\star} P<0.05 \rrbracket\right.$ ** $P<0.01)$. 


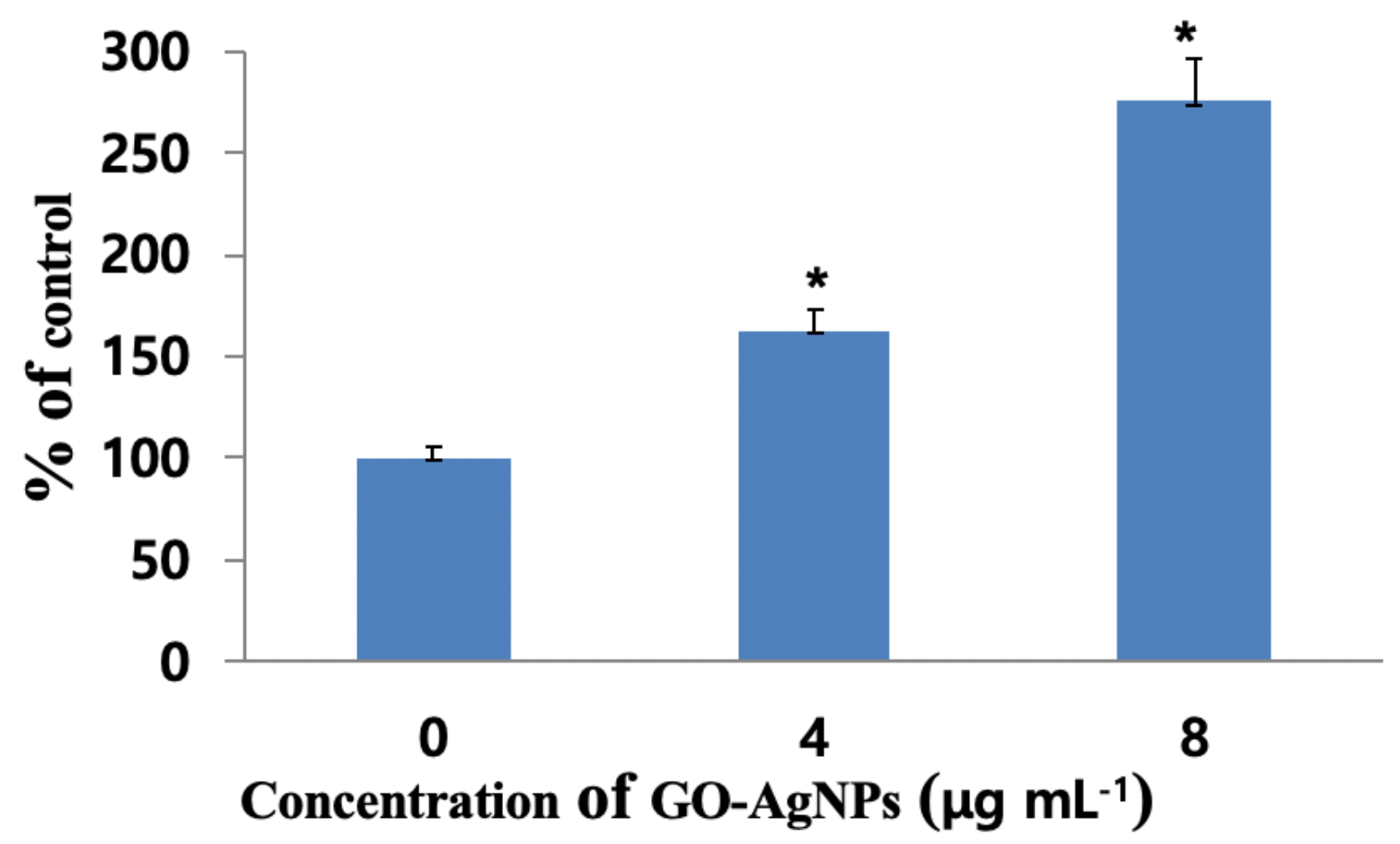

Figure 7

Measurement of MDA production in GO-AgNPs-treated cells. Caprine fetal fibroblast cells were treated with 0,4 and $8 \mu \mathrm{g} / \mathrm{mL}$ of GO-AgNPs for $24 \mathrm{~h}$. The percentage of MDA relative to the control group ( 0 $\mu \mathrm{g} / \mathrm{mL})$ was determined. Values are presented as mean $\pm S D$ of four independent experiments. $\left({ }^{*} P<0.05\right)$. 


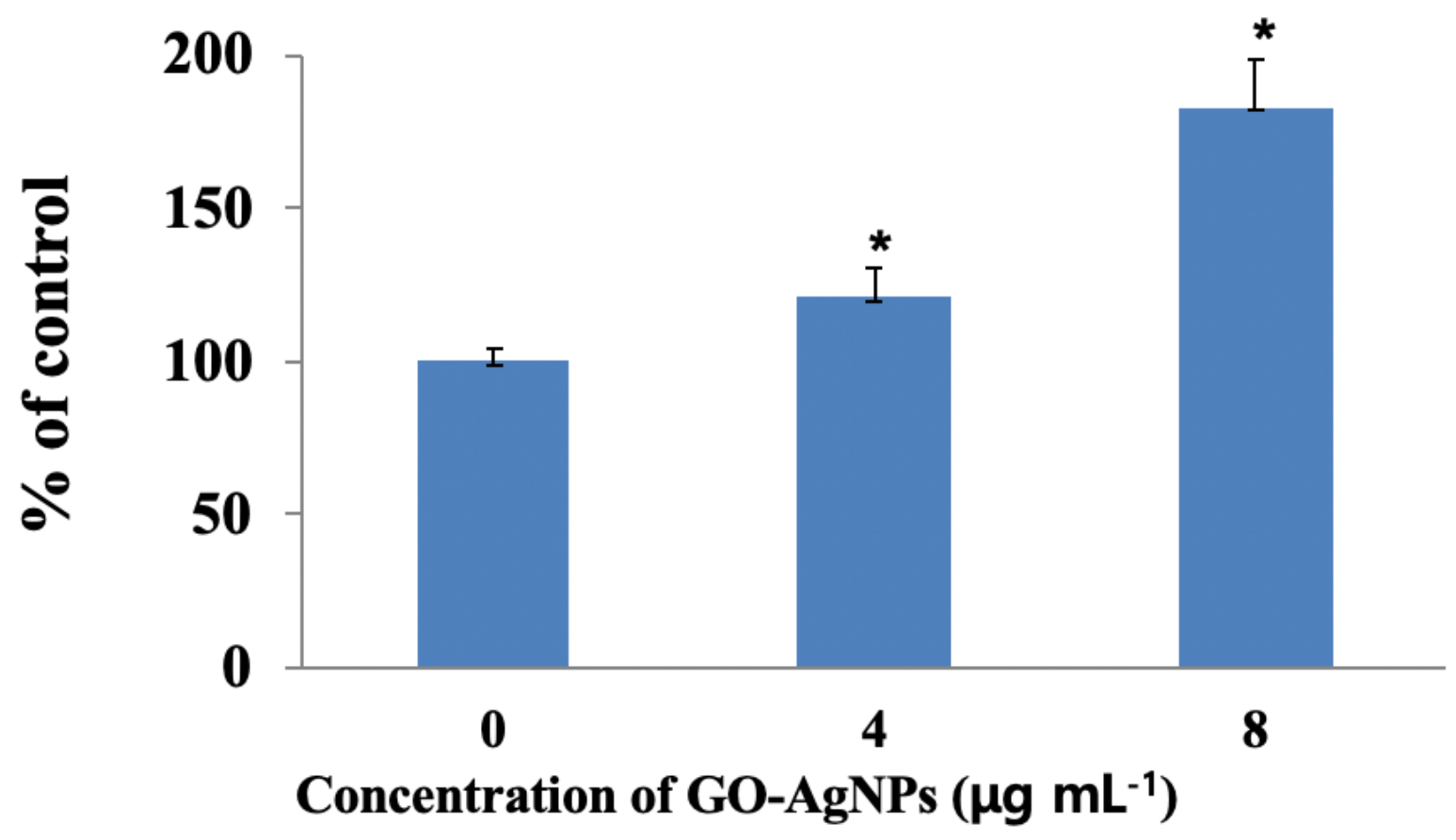

Figure 8

Measurement of LDH activity in GO-AgNPs-treated cells. Caprine fetal fibroblast cells were treated with 0 , 4 and $8 \mu \mathrm{g} / \mathrm{mL}$ of GO-AgNPs for $24 \mathrm{~h}$. The percentage of LDH activity relative to the control group ( 0 $\mu \mathrm{g} / \mathrm{mL})$ was determined. Values are presented as mean $\pm S D$ of five independent experiments. $\left({ }^{*} P<0.05\right)$. 


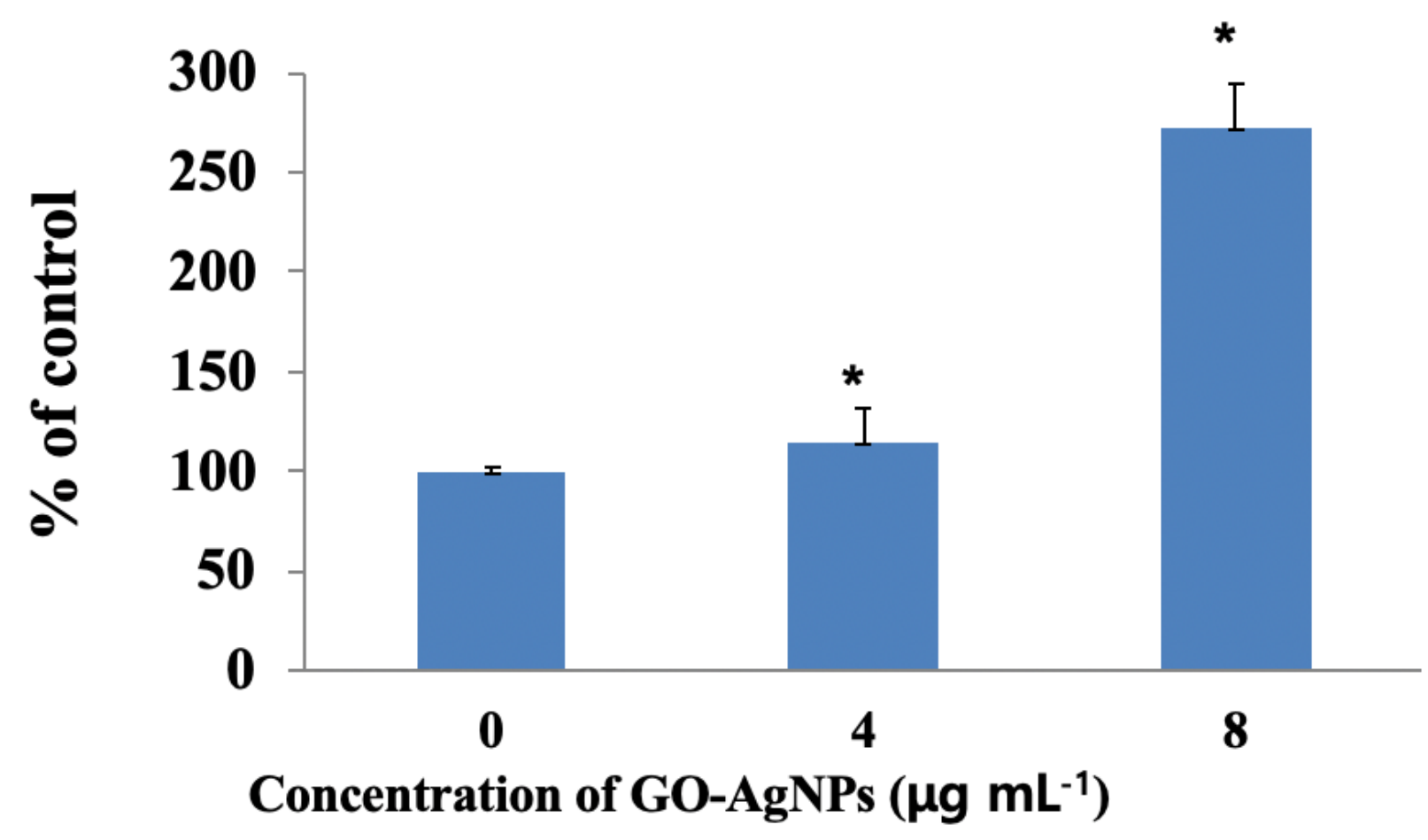

Figure 9

Measurement of caspase-3 activity in GO-AgNPs-treated cells. Caprine fetal fibroblast cells were treated with 0,4 and $8 \mu \mathrm{g} / \mathrm{mL}$ of GO-AgNPs for $24 \mathrm{~h}$. The percentage of caspase-3 activity relative to the control group $(0 \mu \mathrm{g} / \mathrm{mL})$ was determined. Values are presented as mean $\pm S D$ of four independent experiments. $\left({ }^{\star} \mathrm{P}<0.05\right)$. 

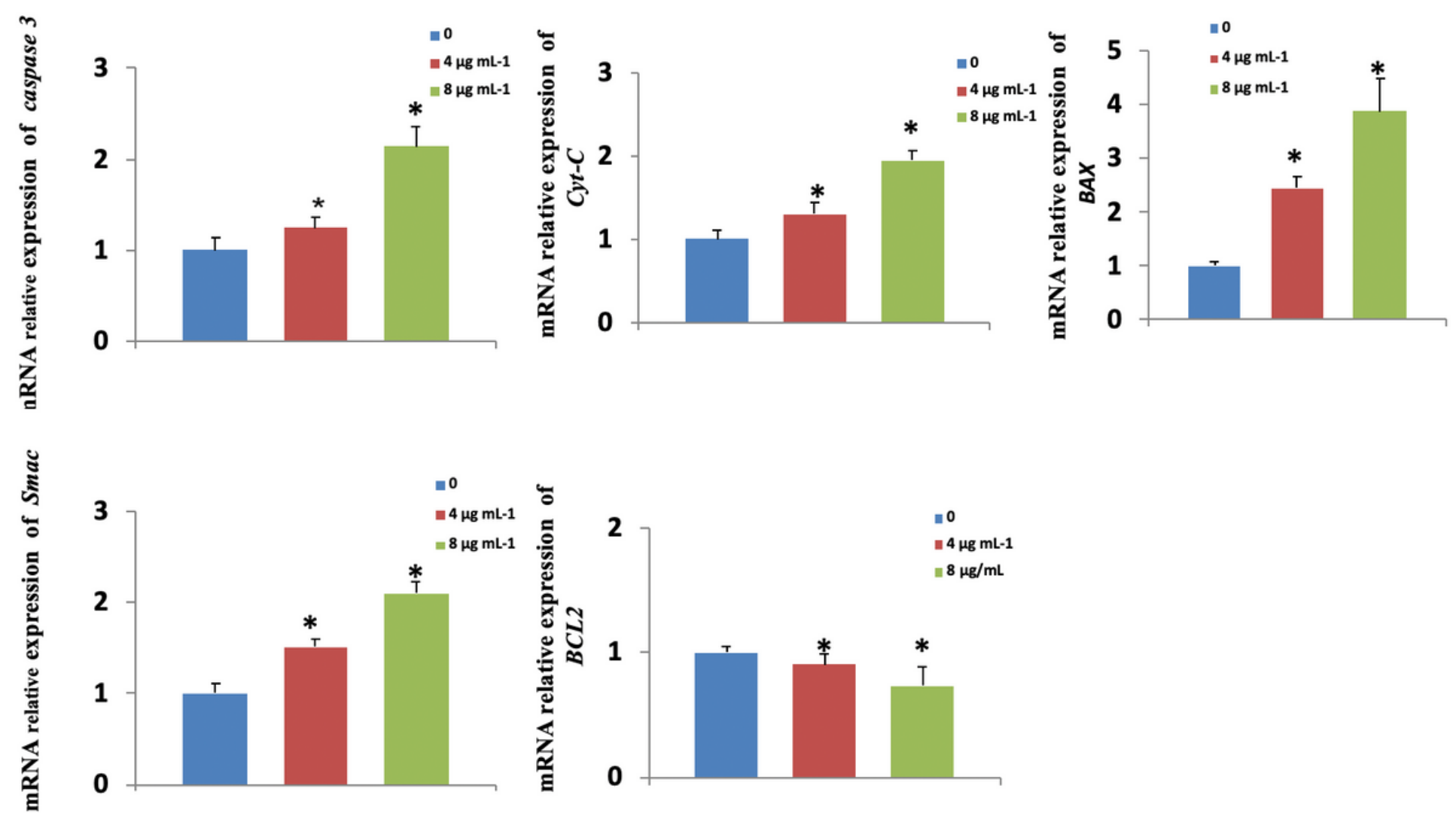

\section{Figure 10}

Effects of GO-AgNPs on apoptotic gene expression levels. Caprine fetal fibroblast cells were treated with 0,4 and $8 \mu \mathrm{g} / \mathrm{mL}$ of GO-AgNPs for $24 \mathrm{~h}$. Relative mRNA levels of genes related to the apoptosis was determined. Values are presented as mean $\pm S D$ of four independent experiments. $\left({ }^{*} P<0.05\right)$. 